\title{
Impacts of Changes in the International Geopolitical Landscape on the Tibetan Tea Trade-From the Ming and Qing Dynasties to the Republican China Period
}

\author{
LIU Zhiyang ${ }^{1}$ \\ Sun Yat-Sen University
}

The sale of Yunnan tea to Tibet began in the late Ming dynasty and the early Qing dynasty, and grew rapidly with many routes of horse caravans entering Tibet. However, for a long period, Tibetan tea produced in Sichuan remained the primary variety sold to Tibet, and it enjoyed irreplaceably important status. In the late Qing dynasty, especially after the Xinhai Revolution in 1911, the relationship between Tibet and the central government weakened under British armed intervention. The sales volume of Tibetan tea produced in Sichuan kept dropping due to unsmooth roads leading to Tibet, excessively high prices and especially the dumping of Indian tea. In the meantime, with the opening of marine corridor of Yunnan tea, the cost of marine transport of Yunnan tea to Tibet was reduced greatly, and its sales volume in Tibet kept on rising. In the early Republican China period, Yunnan tea became the main variety of inland tea in place of Tibetan tea produced in Sichuan. The marine corridor rose when Indian tea was dumped in Tibet after the two Britain-Tibet wars, frustrating Britain's attempt of monopolizing the Tibetan tea market while supplying daily necessities to the Tibetan people, and playing an important role of maintaining connections between Tibet and inland China.

Historically, tea sold to Tibet was produced in Sichuan, Yunnan and Shaanxi Provinces mainly. As one of the main varieties of Tibetan tea, Yunnan tea originates in Fohai (today's Menghai County), Cheli (today's Jinghong City), Jinggu and Mianning (today's Lincang County), Yunnan. The sale of Yunnan tea to Tibet began in the Ming and Qing dynasties, flourished in the Republican China period, and has continued to date.

The tea corridor connecting Tibet and inland tea producing areas is also known as the "Han-Tibetan tea-horse trading road". Historically, the Tibetan Tea Road was a vast traffic network composed mainly of three major main roads (Sichuan-Tibet Road, Yunnan-Tibet Road and Qinghai-Tibet Road (Gansu-Qinghai Road)), and numerous branch and auxiliary roads, spanning the provinces (regions) of Sichuan, Yunnan, Shaanxi, Gansu, Qinghai and Tibet, and extending outward to South Asia, Southeast Asia and West Asia.

Frontier trade between the mainland and Tibet in the Tang and Song dynasties occurred in northwestern China mainly, so the Tang-Tibet Ancient Road became a main trading route. This road runs from the Tang capital Chang'an in the east, through Shanzhou (today's Ledu, Qinghai), Shancheng (today's Xining, Qinghai) and Chiling (Riyue Mountain), the Gaduo Ferry on the Tongtian River, Lieyi (Yushu), the Chawula Pass of the Tanggula Mountains and Hechuan Post Station (Nagqu) to Lasa (Lhasa) in the west (Chen, 1987), and its branch runs through the Himalayas westward to Nepal and Sindhu 
(ancient India). In the Song dynasty, tea drinking prevailed in Tibet. Since the Qinghai-Tibet Plateau produced no tea, all tea consumed in Tibet was from Han areas. At that time, the Song dynasty was in constant war with the Liao, Jin and West Xia countries in the north and northwest. The Song dynasty exchanged tea for warhorses with Tibet. Today's Shaanxi was an important tea-horse trading area then. After the Ming and Qing dynasties, tea sold to Tibet was mainly from Sichuan and Yunnan in the southwest other than from the northwest. Accordingly, for most people today, the familiar Tibetan tea roads are the Sichuan-Tibet and Yunnan-Tibet Roads: the Sichuan-Tibet Road runs from Ya'an, Sichuan through Luding, Kangding, Batang and Chamdo to Lhasa, and the Yunnan-Tibet Road runs from origins of Yunnan tea (today's Xishuangbanna, Pu'er, etc.) through Dali, Lijiang, Zhongdian and Deqinn to Chamdo, then through Pomda and Zayu or Lhorong and Gongbo'gyamda and finally to Lhasa, Shigatse, etc.

Along these two main roads, there are numerous branch roads of various sizes, such as the branch road from Ya'an to Songpan to the south Gansu Tibetan area, that running from the north branch of the Sichuan-Tibet Road through Dengke (today's Dege, Sichuan) to Yushu, Xining and Taozhou (today's Lintan) in Qinghai Province, and that running northward from Chamdo via Riwoche and Dengqen to northern Tibet. This developed tea trading network connects Sichuan, Yunnan and Tibet closely into the highest, steepest and remotest tea-horse trading road in the world.

The major varieties of Yunnan tea sold to Tibet were brick tea, round tea, square tea and bulk tea, in which brick tea was the main variety of Yunnan tea sold to frontier areas, originating in Fohai, Yunnan. Initially, brick tea took the form of "ball tea", and generally mildewed due to long-distance transport. During 1912-1917, heart-shaped brick tea with a handle was created, with seven bricks per barrel, wrapped in bamboo shoot leaves, with a gap between every two bricks for continuous evaporation to avoid mildewing. Brick tea was made from spring tip, Ershui and gain flower tea, and formulated in three layers (bottom, middle and surface), steamed and pressed into bricks, and then packed. ${ }^{2}$

The past changes of the road for selling Yunnan tea to Tibet were closely associated with domestic and international political and economic conditions. It can be said that the rise and changes of this road reflected the political situation and international geopolitical landscape of Tibet relative to the central government, and South Asian and Southeast Asian countries in different periods.

\section{Historical Background of the Rise of Yunnan Tea}

\section{Domestic Factors: Improvement of Traffic between Yunnan and Tibet, and Decline of Sichuan Tea} Sold to Tibet

From the Ming dynasty, the focus of Tibetan tea sale shifted from the northwest to Sichuan gradually. There were two main tea trading roads running from Ya'an and Guanxian - Tibetan tea producing areas in western Sichuan - to the Kham Tibetan area and Tibet: the South Road (Lidiao Road) and the West Road (Songmao Road), where tea sold from such producing areas as Ya'an, Tianquan, Yingjing and Mingshan via Tachienlu to the Kham Tibetan area and Tibet was known as South Road frontier tea, and that sold from such producing areas as Guanxian, Shifang and Pingwu along the Minjiang River, via Mao County, Songpan and Nuoergai to the south Gansu and Qinghai Tibetan areas as West Road frontier tea.

Owing to long distance and traffic blocking between Yunnan and Tibet, Yunnan tea was sold to Tibet in the early Qing dynasty, later than tea sale through the Sichuan-Shaanxi route. In the late Ming dynasty and the early Qing dynasty, tea production in Sichuan was damaged greatly due to long-term wars, resulting in a significant shortage of Sichuan tea sold to Tibet, when Yunnan tea began to rise. In Year 18 of Qing Emperor Shunzhi's reign (1661), the Dalai Lama requested tea trade in Beisheng Prefecture (today's Yongsheng County, Lijiang, Yunnan) (Qi, 2014:317), and then the Qing government set up a tea-horse trade market there, allowing free private trade. A tea market was set up there because this place was located strategically on the border of Yunnan and Tibet (Liu, 2007:416). In Year 4 of Qing Emperor Kangxi's reign (1665), the Qing government revoked the tea and horse supervisory offices in Shaanxi, 
and opened a tea-horse market in Beisheng Prefecture (Zhao, 1977:3655), further improving the status of Beisheng Prefecture in tea-horse trade. Since then, the sale of Yunnan tea to Tibet grew rapidly, with many routes opened, and Yunnan became one of the main sources of Tibetan tea. Its rise was attributed to the following factors:

In the Ming and Qing dynasties, tea planting and processing in Yunnan developed greatly expanding from the six major tea mountains to Mount Ailao, Mengle and the Nushan Plateau in the Lantsang River Basin so forming some tea producing areas in southern Yunnan. The farmers there were expert in tea planting in the mountains in Simao, laying an economic foundation for the sale of Yunnan tea to Tibet. In addition, in the late Ming dynasty and the early Qing dynasty, since southwestern China experienced years of war, the people lived in destitution; the population dropped greatly; and much land was laid idle. From Year 10 of Qing Emperor Shunzhi's reign (1661), the Qing government recruited inland Han farmers to farm on unclaimed wasteland in Yunnan, and promulgated some preferential policies, such as tax exemption for the first three years (Qing, 1985:49). After the change of the tribal chieftainship system to the standard Chinese bureaucratic system during Qing Emperor Yongzheng's reign, former domains of chieftains became newly opened minority domains (Qing, 1985:907). In Year 1 of Qing Emperor Qianlong's reign (1736), the Qing government no longer restricted migrants going to southwestern frontier areas for reclamation, and allowed them to reclaim odd pieces of land (Qing, 1985: 811). Then, a large number of Han people from Hunan, Hubei, Sichuan, Guangdong and Guizhou Provinces migrated to tea producing areas in Yunnan, who settled there, either dealing with trade or reclaiming land." (Jiang, 1987:1233) Incoming inland migrants brought inland tea making techniques, and improved the quality of Yunnan tea.

Furthermore, with the transfer of Yunnan troops to Tibet during the reigns of Qing Emperors Kangxi and Yongzheng, traffic conditions between Yunnan and Tibet were improved, and Yunnan merchants began to enter Tibet for tea trade. In particular, after the opening of the railway from Indian seaport Calcutta to Darjeeling on the south piedmont of the Himalayas in 1888, the time of traveling from Calcutta to Lhasa was shortened greatly to less than one month. It took six or seven months to transport goods from Kangding to Tibet (Sichuan, 1999:247).

The decline of Sichuan tea also became an important reason for the rise of Yunnan tea. Owing to the policy of "governing borders areas with tea" pursued by the Qing government, heavy taxes levied on Tibetan tea, and the corrupt bureaucracy, tea trade became unprofitable, the tea industry was depressed, the market was full of inferior tea, and Sichuan tea got a bad reputation in Tibet. After the second British invasion of Tibet, Indian tea was dumped in Tibet, aggravating the decline of the sale of Sichuan tea to Tibet. In addition, Sichuan tea was unusually expensive when transported to Lhasa. According to the statistics of E.C. Baber at the late Qing dynasty, tea worth 200 pennies per 5.5 kilograms in Yingjing County was sold for 1,240 pennies in Tachienlu, while its price in Lhasa was 20 times more than that in Tachienlu (Baber, 1882:193).

The Qing government set up customs passes in Tachienlu (Kangding), prohibiting Han merchants from entering Tibet, who sold their goods to Tibetan merchants for sale to Tibet. Forwarding merchants in Xikang put goods in cartons wrapped in cowhide or directly in cowhide, and transported goods with cattle and horses, because this area featured barren land, rugged roads and harsh weather, and goods were likely to be damaged (Zhang, 2005:399). In contrast, the Qing government had weak control over the Lijiang, Zhongdian, Jianchuan and Atuntze (Deqen) route with less customs passes. Compared to Sichuan tea merchants, Yunnan merchants most entered Tibet for transport and sale.

Owing to the above factors, Yunnan tea was sold to Tibet in large quantities. In the late Qing dynasty and the Republican China period, horse caravans transporting Yunnan tea could enter Tibet directly. In the Republican China period, there were over 20 Yunnan firms doing business in Lhasa, mostly selling bowl tea (Han, 1984:96). Before the peaceful liberation of Tibet in 1951, there was a Yunnan provincial guild in Lhasa, and Yunnan merchants transported Yunnan tea to Tibet via two routes: the land route passed 
through Myanmar, and the marine route through India (Xing, 2003:200). Yunnan tea was not only sold to the Deqen Tibetan area and Tibet, but also sold well in the Kham Tibetan area.

\section{International Environment: Pressure of Indian Tea Dumping and Conclusion of Unequal Treaties}

In the mid of $17^{\text {th }}$ century, tea was introduced into Britain. From the $18^{\text {th }}$ century, the custom of tea drinking became popular in Britain, and the demand for tea grew surprisingly. The British love for tea surpassed any other European country. In addition, the growing demand of the British for tea triggered two major events in the world history - the American Revolution and the China-Britain Opium War.

The outbreak of the Opium War was attributed to the sharp growth of British tea imports. In 1790, the East India Company imported 14.69 million pounds of tea from China. At the end of the $18^{\text {th }}$ century, with the revocation of British tea import tax, tea import volume rose sharply to 20.35 million pounds in 1800 to 30.04 million pounds in 1830 and sharply to 40.67 million pounds in 1839 before the Opium War. In the first half of the $19^{\text {th }}$ century, the per capita tea consumption in Britain grew moderately from 1.5 pounds in 1800 to almost 2 pounds in 1850 . However, due to the rapid growth of the British population in this period, actual gross tea consumption actually doubled, and the tea was almost all imported by the East India Company from China (Moxham, 2010:62).

In contrast to the growing tea demand in Britain, China has almost no demand for Britain commodities except silver. This was because with the reform of the Chinese taxes and corvee system during the $16^{\text {th }}-18^{\text {th }}$ centuries, silver played a very important role at the state level, i.e., the operation of the state government organs then relied on silver, and almost all silver of China was imported. The British exchanged American silver for Chinese tea and other goods so that silver inflows entered the national fiscal system quickly, and were largely stocked up by the treasury, emperor and magnates. Therefore, some scholars suggest that the large-scale import of silver then avoided potential serious inflation (Chen and Liu, 2010).

Owing to the tremendous trade deficit between China and Britain, the British government began to encourage merchants to export opium planted in India into China to offset the deficit of tea trade. In August 1842 after the China-Britain Opium War in 1840, the defeated Qing government was forced to sign the unequal Nanjing Treaty with Britain. Afterwards, great powers like France and the U.S. also signed a series of unequal treaties with the Qing government. After the Opium War, Britain further expanded opium exports to China, causing severe damages to the Chinese economy. Although this war was called the Opium War, an important cause of its outbreak was Britain's expanding demand for tea, and the tremendous trade deficit between China and Britain.

From the $18^{\text {th }}$ century, the East India Company began to study the feasibility of planting tea in India in order to break the tea monopoly of the Qing government and reduce its trade deficit with China. When British envoy Macartney passed through a tea producing area in Jiangxi Province during his visit to China in 1793, he took away several tea trees with soil with the consent of local officials, and carried them to Bengal for research and trial planting (Morse, 1926: 229). In 1833, William Bentinck became Indian Viceroy, and began to study planting tea in India. In 1834, a tea committee was founded in Britain to introduce tea and seeds from China.

From the $19^{\text {th }}$ century, the East India Company kept expanding to the Himalayan region. In 1826 , the British seized Assam bordered by Bhutan, a river valley with lush trees in the Yarlung Tsangpo River Basin, ideal for plant growth. The British quickly found wild tea trees there, so Indian Viceroy Dr. Bruce set up the first tea plantation there. Owing to the poor taste of the local wild tea, Dr. Bruce tried to smuggle tea seeds and growers from tea producing areas of China. In the search for the best tea species, the East India Company assigned British gardener Robert Fortune to Chinese tea producing areas to collect plant samples and tea seeds in 1843. Fortune bought large quantities of high-grade tea seedlings and seeds in Anhui Province, and transported them to India along with some tea growers and whole sets of tea making tools (Rose, 2010:141). In the mid $19^{\text {th }}$ century, Britain planted tea in Assam successfully. From 1860, Britain started extensive tea garden construction there, and expanded tea planting to Nepal 
and Sri Lanka. Afterwards, the output of Indian tea kept rising, with a gross output value of 60,533 British pounds in 1859 and 262,0140 British pounds in 1877, an increase of 45 times (Dutt, 1969:347). In 1880, the tea planting area of Britain on the south piedmont of the Himalayas reached 843 square kilometers, with three fourths in Assam. In 1888, the quantity of tea imported by Britain from India exceeded that from China for the first time, and tea became excess with the saturation of domestic demand (Moxham, 2010:113).

In order to promote the sale of excess tea, British India began to think of how to dump tea to the tea-loving Tibetans across the Himalayas in Tibet and northwestern China. George Bogle, who was assigned by the East India Company to Tashilhunpo Monastery as an envoy as early as 1780, was impressed by the tea drinking custom of the Tibetans. He described this as follows: "All people drink tea in the style of the Tatars, and those personages drink tea all the day" (Markham, 1879:51). This might be the first time when the British noticed the tea drinking custom of the Tibetans, and enhanced their understanding of this custom.

The entry of Indian tea into Tibet had been prohibited before the Shimla Conference. For example, a Darjeeling merchant smuggled Indian tea into Tibet in large quantities in 1872, but was arrested and imprisoned for three years in Phari on the Tibet-Bhutan border (Macaulay, 1885:89-91). After winning the first Britain-Tibet war, Britain signed the unequal Tibet-India Treaty with the Qing government and the Tibet local government in 1890, and the Renewed Tibet-India Treaty in 1893. According to the two treaties, Britain not only turned Dremojong (Sikkim) formerly affiliated to the Tibetan local government into its protectorate, but also got the privilege of access to port and cargo trade with five-year tax exemption in Yatung, opening the door for selling Indian tea in Tibet. ${ }^{3}$ However, the Tibet local government did not observe the relevant provisions of these treaties afterwards, and Han and Tibetan merchants were prohibited from doing business in Yatung. Yatung was located at the southernmost tip of the Chumbi Valley, with no civil residence, no resident, no food supply and no bazaar, and with only a small piece of river flat as an open zone. In 1894, German wool trader J.M. Korb sent a meeting notice to Tibetan merchants and local officials before coming to Yatung for trading, but no one appeared at the meeting. Korb felt helpless about this: "Yatung is unsuitable as a trading port" (Liu, 1997:61). The Tibet local government set up a customs pass in Phari that was truly open to trade, and prevented merchants of India and Sikkim from trading in Tibet, especially Indian tea (Liu, 1997:63), so that British merchants in India kept filing complaints with the British government. On the other hand, the Qing government and the Tibetan local government rejected the unreasonable request of British Indian Viceroy G.N. Curzon that the trading place be transferred from Yatung to Phari, and traders could contact the Tibetan local government directly (Lamb, 1960:241). After the failure of the negotiation between the Chinese and British sides in Ganba in 1903, the British government decided to take a military action using this as an excuse. Curzon assigned Francis Younghusband to attack Tibet in 1903. After the British troops occupied Lhasa, the Qing government and the Tibetan local government were forced to sign the Lhasa Treaty, opening up the road from India to Tibet and gaining trading rights in Tibet. In 1908, the agreement between Britain, China and Tibet Amending the Trade Regulations of 1893 was signed, which allowed the import of Indian tea into Tibet. All customs passes from Yatung and Phari to Gyantse and Shigatse were withdrawn, and Indian goods entered Tibet without any obstacle. In particular, the seizure of the Chumbi Valley changed the former Yatung-Tibet route, and reduced transport costs greatly. Francis Younghusband attacked Tibet for the purpose of seizing the Chumbi Valley and controlling the trade route for the export of Indian tea into Tibet (Younghusband, 1934:243-244). Afterwards, Britain built a road from the Chumbi Valley to Gyantse.

In 1826, the British seized Assam to border Bhutan. In 1835, British India leased Darjeeling from Dremojong as its Tibetan access base and transfer station. In 1861, the British defeated Dremojong, and got the railway right throughout Dremojong, making the central route of India-Tibet traffic smooth, and granting the British direct access to the Tibetan border via Darjeeling. In 1865, British India further defeated Bhutan, which ceded territory for peace, so the road between Bhutan and Tibet was also opened. 
After conquering Myanmar and Sikkim, Britain immediately built a road to the southwest frontier of China. In 1879, British India completed the highway from Darjeeling to Mount Rina south of the Chumbi Valley. In 1881, the railway from Siliguri to Darjeeling was opened, and in 1886, the Darjeeling Railway was formally opened, so that trains could run from Calcutta in India to the Tibet frontier directly. In Myanmar, the railway from Yangon to Mandalay was opened in 1889, and the branch railway from Mandalay and Lashio was completed in 1902, so that tea from Yunnan tea producing areas could be transported in Lashio via Mandalay to Yangon by train, to Calcutta by ship, then from Calcutta to Kalimpong by train, and finally via the south piedmont of the Himalayas to Tibet by mule and horse.

\section{Rise of the Land and Marine Corridors for the Sale of Yunnan Tea for Tibet}

Yunnan tea was sold to Tibet either by land or sea. There were three land routes - one from Fohai the main producing area of brick tea - via Simao, Jingdong, Lijiang, Deqen and Chamdo to Lhasa, another from the Lantsang River, Shuangjiang River, Mianning, Yunxian County, Shunning, Menghua, Xiaguan, Lijiang, Deqen and Chamdo to Lhasa; and the other from Kunming, Yuanmou and Huili to Kangding.

In the Qing dynasty and the Republican China period, tea sold from Yunnan to Tibet was transported by horse caravans mainly, from Pu'er and Simao, via Dali, Lijiang, Yongning and Muli to Tachienlu (Kangding), with some sold to Tibetan merchants in Kangding, and some further transported to Lhasa for sale. In addition, Tibetan horse caravans also purchased tea in Yunnan, and would go to Simao and Menghai in an endless stream in every spring and autumn, sometimes with up to 4,000-5,000 horses. They would sell some horses and returned with bought tea. Several famous major bazaars in western Yunnan, such as the March Fair in Dali and the Mule-Horse Fair in Lijiang, were also good opportunities for Tibetan horse caravans for exchanging goods and buying tea. At that time, large-scale Tibetan horse caravans traded in fur, musk, antlers, fritillary, Cordyceps sinensis and other Tibetan specialties, and carried back tea when returning.

The Yunnan-Tibetan tea-horse land routes were mostly located in high mountains. Since southwestern Yunnan was hot with frequent plagues in the rainy period, when humans, mules and horses were likely to become ill, caravans usually passed from northwestern Yunnan through this region to Tibet before the May rainy period. Passage was difficult in summer when leeches prevailed and winter when mountains were covered by snow.

In the early Republican China period after the Xinhai Revolution, the situation of the Sichuan-Xikang region deteriorated by frequent warfare and active bandits, so that merchants deemed the Tibet-going route via Atuntze to be dangerous, and the land trade of Yunnan tea began to decline. Accordingly, most Yunnan tea was transported from Fohai via Yangon in Myanmar by land, to India by sea, and then to Tibet by land. This route became the marine route for the sale of Yunnan tea to Tibet.

After completion of the railway leading to Darjeeling in 1881, Yunnan merchants tried going to Lhasa from Shanghai, Calcutta, Darjeeling and Yatung as an alternative to the long land route from Chengdu via Tachienlu and Chamdo. In this Yunnan tea route making a detour via Southeast Asia and South Asia from Yunnan to Tibet, tea was transported from tea producing areas such as Simao and Xishuangbanna via Kengtung and Yangon in Myanmar by land, to Calcutta in India by sea, then to Darjeeling or Kalimpong by train, and finally from the south piedmont of the Himalayas to Tibet by mule and horse. This route was one of the main routes for the sale of Yunnan tea to Tibet in the Qing dynasty and the Republican China period. Convenient ship or railway transport was available throughout the route from Yunnan (by sea) to Yatung in Tibet except the last 300 miles (Lamb, 2002:178). After 1925, the number of Yunnan merchants doing tea business via this route increased gradually.

All goods entering Tibet from India had to pass through Kalimpong - the trading center of the Himalayan region, first going northward from Calcutta for 327 miles to Siliguri by train, then to Geillekohla 29 miles north by small train, and finally to Kalimpong by cable car. There were two mountain routes entering Tibet from Kalimpong. 
One route passed through the Zalila Mountain Pass: from Kalimpong to Zalila (4 days), from Zalila to Natang (4 days), from Natang to Phari (4 days) and from Phari to Lhasa (13 days). This was the main corridor between India and Tibet, and could be used by both humans and livestock (Li, 2000:91).

The other route passed through the Ladola Mountain Pass and Sikkim, with 12 stops in total: 1) Jenbu; 2) Sikkim; 3) Bendenmeli; 4) Jensigang (all mountain roads afterwards); 5) Jima; 6) Bibidang; 7) Yatung; 8) Glika; 9) Ribigang; 10) Gano; 11) Phari; and 12) Lhasa. The time taken to pass through this route was almost the same as the first one. In 1904 after the second British invasion of Tibet, British troops were stationed in Chumbi, Tibet, Chumbi was turned into a trading port, and a path from the Ladola Mountain Pass to Chumbi was built. In 1923, the trade route from Sikkim to Ladola was further built, further facilitating the entry of goods from Sikkim into Tibet (Liu, 1997:160).

Goods transported from Kalimpong to Tibet had to be carried by mules and horses, with each fleet containing at least 100 mules and horses. Each mule or horse could carry about 70 kilograms, where tea was contained in two packs on both sides of the back, and covered with oil cloth for weatherproofing. From each October to next March, Tibetan caravans would carry Tibetan specialties to Kalimpong, buy Yunnan Kalimpong there after selling goods, and backtrack to Lhasa. This period was chosen to avoid rains mainly.

With the opening of the Yunnan-Myanmar Highway after the outbreak of the Anti-Japanese War, Yunnan tea could be transported to Myanmar by truck, then to India by sea and then to Tibet by land, or directly from Menghai via Myanmar to Tibet by railway and water. High transport volumes reduced transport costs greatly.

Since neither the Tibet local government nor British India levied customs (Liu, 1997: 40-41), costs of selling Tibetan tea by sea were lower than those of Sichuan tea. In 1936, 750,000 kilogram of Yunnan tea was sold in Tibet, with per capita consumption of 0.75 kilogram (based on a Tibetan population of 1 million) (Tan, 1944). According to the 1954 archives of the Commerce Department of the Tibet Autonomous Region, from 1942 to 1954, 2,000-4,000 mules and horses entered Tibet from Yunnan, carrying in 600-1,700 loads of tea with a total weight of 550,000 kilograms. According to a survey by Tibet Trade Corporation in Kalimpong, India, 6,000 loads of brick tea with a total weight of 330,000 kilograms were imported from Kalimpong via Yatung in 1951 (Li, 2000: 18). The volume of Yunnan tea transported by sea was much more than that transported by land.

TABLE 1 SALES VOLUMES OF YUNNAN TEA PRODUCED IN FOHAI TO TIBET IN
THE REPUBLICAN CHINA PERIOD

\begin{tabular}{|c|c|c|c|c|c|c|}
\hline Year & 1928 & 1930 & 1932 & 1934 & 1936 & 1938 \\
\hline Volume (dan =50kg) & 5000 & 6000 & 10000 & 12000 & 15000 & 18000 \\
\hline Local price (silver dollar) & 8 & 8 & 9.5 & 9 & 12.3 & 14.6 \\
\hline Total amount & 40000 & 48000 & 95000 & 108000 & 184500 & 262800 \\
\hline
\end{tabular}

Source: Tan Fangzhi, Sale of Yunnan Tea to Tibet, Public Opinions on Frontier Politics, Volume 3, Issue 11

After 1911, tea sold from inland China to Tibet was almost all Yunnan tea, while Sichuan frontier tea was sold to Xikang mainly, with only a small amount of high-grade fine tea transported to Tibet for consumption by nobles and senior monks (Ren, 1990:260). In 1941, investigator Wang Kexun assigned by the Mongolian and Tibetan Affairs Commission to Xikang said after examining the economic situation of Xikang, "Tea merchants in Xikang are now selling Yunnan tea due to poor past business." (Tang, 2005: 421)

In the 1940s, most Yunnan tea merchants in Lhasa were from Yunnan (Han, 1984:96). Han monk Xing Suzhi, who lived in Lhasa in the 1940s, recalled the head of the Lhasa Yunnan Guild was Zhang 
Xiaozhou, who not only had business in Lhasa, but also set up a branch in Kalimpong, India (Xing, 2003:200). Among Yunnan merchants, Ma Shiyuan was most senior, who came to Tibet to deal with tea, jewelry and wool when he was young. Other Yunnan merchants and firms also included Ma Lianyuan, Zhu's, Liu Futang, Zhang Xiaozhou, Heng Xiaozhou, Heng Shenggong, Hong's, etc (Li, 2000:36). Except Yunnan merchants, some Sichuan merchants also dealt with tea on a small scale in Lhasa. Section Chief Li Youyi of the Tibetan Office of the Republic of China government pointed out after examining the Lhasa market, "There are at most over 30 Yunnan merchants, dealing with the import of tea, copper, food, etc" (Li, 1951:87).

Yunnan tea sold to Tibet was used to prepare butter tea - a traditional Tibetan tea drink, and was highly popular among the Tibetans due to its mellow taste. However, from the early $20^{\text {th }}$ century, Indian tea imitating Xikang brick tea and Yunnan bowl tea also entered the Tibetan market in large quantities. In the early 1940s, General Manager bskal bzang ye shes of Xikang-Tibet Trading Company found after visiting Kalimpong that there were several Tibetan tea firms run by Indians and Britain in Kalimpong, among which two were larger. One was Indian firm, which exchanged imitated Xikang brick tea and Yunnan bowl tea for Tibetan wool, and produced 7.5 tons of brick tea and 35 tons of bowl tea annually; the other was the firm of British, which produced 2,000 packs of imitated Fohai bowl tea annually (Bskal Bzang, 2005:336).

The sale of Yunnan tea to Tibet did not go smoothly, because the British Indian government often prevented Chinese merchants residing in India from traveling between India and Tibet. On September 2, 1912, Cantonese merchant Lu Xingqi running Tianyi Firm in Calcutta called President Yuan Shikai, alleging "The British envoy interfered with Tibetan affairs..... disallowing Chinese to go to Tibet from India."(Wu, 1983:34) Since tax exemption for commodities entering Tibet from India covered Tibetan nobles and merchants only, Han merchants had to buy a tax exemption certificate issued by the British from Tibetan nobles or merchants, and such certificate became a considerable income source for Tibetan nobles then (Xing, 2003:203). Tibetan tycoons such as Punda Tsang, Sadu Tsang and Tsha Rong had established firms in Kalimpong and other places to deal with wool and tea, in which Sadu Tsang was the Tibetan dealer of a British great tea merchant, and his commission was one tenth of the after-sales price.

\section{CONCLUSION}

Tibetan is one of the ethnic groups that like drinking tea the most in the world, and tea drinking is an essential part of their daily lives. According to available Tibetan and Han historical records, tea drinking in Tibet can be dated back to the Btsan-po period, namely the Tang dynasty in inland China, when tea was not popular in the Qinghai-Tibet Plateau, and was a rare drink available to nobles and monks and even a good drug. In the Song dynasty, with the intensification of tea-horse trade between Tibet and the Song dynasty, tea entered Tibet in large quantity, and tea drinking quickly became popular in all classes of Tibetan society as a custom and lifestyle. In the Ming and Qing dynasties, tea became a daily necessity for the Tibetans. As a Tibetan proverb states, "One would rather refrain from food for three days than refraining from tea for one day." However, although the tea drunk by the Tibetans is called "Tibetan tea", it is not produced in Tibet, but in tea producing areas in Ya' an and Pingwu in Sichuan Province, southwestern Yunnan Province and southern Shaanxi Province. In view of the importance of tea for the Tibetans, tea was controlled by the governments of the past central dynasties as an important means of controlling non-Han people. However, from another perspective, tea had greater political significance than economic significance in maintaining the relationship between the government of the central dynasty and Tibetan areas.

The sale of Yunnan tea to Tibet began in the late Ming dynasty and the early Qing dynasty, and grew rapidly with many routes of horse caravans entering Tibet. Dali and Lijiang in Yunnan Province rose quickly as transfer and distribution hubs of Yunnan tea entering Tibet. However, for a long period, Tibetan tea produced in Sichuan remained the primary variety sold to Tibet, and enjoyed irreplaceably important 
status. In the late Qing dynasty, especially after the Xinhai Revolution in 1911, the relationship between Tibet and the central government weakened under British armed intervention. The sales volume of Tibetan tea produced in Sichuan kept dropping due to unsmooth roads leading to Tibet, excessively high prices and especially the dumping of Indian tea. In the meantime, with the opening of marine corridor of Yunnan tea, and the signing of the Yunnan-Myanmar Commercial Treaty between China and Britain, and the Amended Tibet-India Trade Regulations between China and Britain, which stipulated that no tax was to be levied among Yunnan, Myanmar, Tibet and India, the cost of marine transport of Yunnan tea to Tibet was reduced greatly, and its sales volume in Tibet kept rising. In the early Republican China period, Yunnan tea became the main variety of inland tea in place of Tibetan tea produced in Sichuan. In the Republican China period, Indian and Yunnan teas became the main varieties of Tibetan tea sold in Tibet. This situation did not change until 1959, when Ya'an frontier tea became the main variety of Tibetan tea again.

The marine corridor rose when Indian tea was dumped in Tibet after the two Britain-Tibet wars, frustrating Britain's attempt of monopolizing the Tibetan tea market while supplying daily necessities to the Tibetan people, and playing an important role of maintaining connections between Tibet and inland China.

\section{ENDNOTES}

1. Liu Zhiyang is a professor at School of Sociology and Anthropology, and a research fellow at Centre for Historical Anthropology in Sun Yat-sen University, China. This study was supported by a grant from Guangdong Planning Office of Philosophy and Social Science (GDXK201703).

2. Brick tea is made by picking, processing and packing, in which picking includes collection and sorting, processing includes screening, mixing, weighing, steaming, rubbing, pressing, unpacking and re-drying, and packing includes inner and outer packing.

3. In February 1890, the Qing government assigned Sheng Tai to Calcutta to sign the Tibet-India Treaty with British Indian Viceroy Lansdowne, not only admitting that Sikkim was protected by Britain, but also redefined the border between Tibet and Sikkim as required by the British, so that China lost a lot of land. In 1893, after Sheng Tai's death in 1892, the Qing government assigned He Changrong to sign the Renewed Tibet-India Treaty with the British in Darjeeling, stating that China would open up Yatung as a trading port, where the British were entitled to extraterritorial jurisdiction here, and also that goods imported via the Tibet-Sikkim border would be tax-exempted for five years. 


\section{REFERENCES}

Bskal Bzang Ye Shes (格桑悦希). 2005. “Overview of the Sale of Indian Tea in Tibet.” In Selected Archives on the Economic Development of Tibet and Tibetan Areas in the Republican China Period, edited by China Tibetology Research Center and the Second Historical Archives of China. Beijing: China Tibetology Publishing House.

Chen Chunsheng, Liu Zhiwei. 2010. "Tribute, Market and Material Life: A Tentative Discussion of the Relationship between Silver Import from America and China's Social Changes in the $18^{\text {th }}$ Century." Journal of Tsinghua University, 5:65-81..

Chen Xiaoping. 1987. "Direction and Route of the Tang-Tibet Ancient Road." Qinghai Social Sciences, 1987 Issue 3

Baber, Edward Colborme. 1882. "Travels and researches in western China." Royal Geographic Soceity Supplementary Papers 1(1): 15-180.

Dutt, Romesh Chunder. 1969. Economic History of India. Himalaya Publishing House.

Han Xiujun, 1984. "Notes on Beijing Merchants Doing Business in Lhasa"(北京商人在拉萨经商略记). In Selected Tibetan Cultural and Historical Data (Vol. 3) (《西藏文史资料选辑》第三辑),edited by Cultural and Historical Data Research Committee of the Political Consultative Conference of the Tibet Autonomous Region. .

Jiang Junyuan (江䜭源).1987.“An Audit on Non-Han Affairs”（条陈稽查所属夷地事宜）.In Notes on Southern China History and Geography (《中国西南历史地理考释》), edited by Fang Guoyu ( 方国瑜). Beijing: Zhonghua Book Company.

Lamb, Alastair. 1960. Britain and Chinese Central Asia: the Road to Lhasa 1767 to 1905. Routledge and Kegan Paul.

Lamb, Alastair. 2002. "Trade between India and Tibet", Wu Kunming, trans. In Collection of Translations of Foreign Tibetan Studies (Vol. 16), edited by Wang Yao, Wang Qilong. Lhasa: Tibet People's Publishing House.

Li Jianshang. 2000. "Commerce and Trade of Tibet." In Survey on Commerce and Handicrafts in Tibet, edited by Institute of Nationality Studies, Chinese Academy of Social Sciences, and Social and Economic Institute, China Tibetology Research Center. Beijing: China Tibetology Publishing House.

Li Youyi. 1951. Today's Tibet. Tianjin: Knowledge Bookstore.

Liu Wukun. 1997. History of the Yatung Customs Pass (西藏亚东关史). Xuzhou, Jiangsu Province: China University of Mining and Technology press.

Liu Jingmao (刘景毛).2007. New General Records of Yunnan No.3 (刘景毛点校: 《新纂云南通志 3》, Kunming: Yunnan People's Publishing House.

Liu Wukun. 1997. History of the Yatung Customs Pass. Xuzhou: China University of Mining and Technology Press.

Macaulay, Colman. 1885. Report of a mission to Sikkim and the Tibetan frontier: with a memorandum on our relations with Tibet. Calcutta: Bengal Secretariat Press.

Markham, C.R. 1879. Narratives and of the Journey of Thomas Manning to Tibet to Bogle of the Mission of George Lhasa. London: Trubner and Co., Ludgate Hill.

Morse, H.B. 1926. "The Chronicles of the East India Company Trading to China, 1635-1834." The Journal of the Royal Asiatic Society of Great Britain and Ireland, 3:229.

Moxham, Roy. 2010. Tea: Custom, Exploitation and the Empire. Bi Xiaoqing, trans. Beijing: SDX Joint Publishing.

Qi Yunshi (祁韵士[清]). 2014. “Synopsis of Non-Han Tribes No. 1, Synopsis of Tibetan Tribes Volume 17” (《皇朝藩部要略》卷 17 《西藏部要略一》).In Qi Yunshi’s Collection (《祁韵士集》), edited by Liu Changhai (刘长海).Taiyuan: Sanjin Publishing House. 
Qing Official Recorders. 1985. “Chronicle of Hong Ancestor Vol.1”(《圣祖实录》卷 1).In Qing Records Vol.54 (《清实录》第 4 册). Beijing: Zhonghua Book Company.

Qing Official Recorders. 1985. “Chronicle of Qianlong Vol.54” (《高宗纯皇帝实录》卷 54). In Qing Records Vol.9 (《清实录》第 9 册). Beijing: Zhonghua Book Company.

Qing Official Recorders. 1985. “Chronicle of Qianlong Vol.123” (《高宗纯皇帝实录》卷 123). In Qing Records Vol.10 (《清实录》第 10 册). Beijing: Zhonghua Book Company.

Ren Hanguang. 1990. "Investigation Report on Guozhuang, Kangding." In Selected Modern Archives of the Kham Tibetan Area, edited by Sichuan Archives and Sichuan Ethnic Institute. Chengdu: Sichuan University Press.

Rose, Sarah. 2010. For all the Tea in China: How England stole the world's favorite drink and changed history. Viking Penguin Incorporated.

Sichuan Archives and Sichuan Ethnic Institute. 1999. "Records of Tea Merchants in July 1935." In Selected Modern Archives of the Kham Tibetan Area. Chengdu: Sichuan University.

Tan Fangzhi. 1944. “Sale of Yunnan Tea to Tibet (滇茶销藏)." Public Opinions on Frontier Politics (边 政公论) 3 (11).

Tang Lei. 2005. "Report of Tang Lei, Leader of the Xikang Investigation Group on the Xikang-Tibet Economic Situation, and Comments of Wang Kexun." In Selected Archives on the Economic Development of Tibet and Tibetan Areas in the Republican China Period, edited by China Tibetology Research Center and the Second Historical Archives of China. Beijing: China Tibetology Publishing House.

Wu Fengpei. 1983. Tibetan Telegram Drafts of the Republican China Period. Lasha: Tibet People's Publishing House.

Xing Suzhi (Lobsang Zhindrup). 2003. A Quest for Dharma in the Snow Land: Narrative of a Han Lama (雪域求法记: 一个汉人喇嘛的口述史), recorded and written by Zhang Jianfei and Yang Nianqun. Beijing: SDX Joint Publishing.

Younghusband, Francis. 1934. History of the British Invasion of Tibet (英国侵略西藏史), Sun Xuchu, trans. Beijing: Commercial Press.

Zhang Mao (张禁). 2005[1935]. "Report of Inspector Zhang Mao on the General Situation of Xikang”(巡 员张禁关于西康概况呈文). In Selected Archives on the Economic Development of Tibet and Tibetan Areas in the Republican China Period (《民国时期西藏及藏区经济开发建设档案选编》 ), edited by China Tibetology Research Center and the Second Historical Archives of China. Beijing: China Tibetology Publishing House.

Zhao Erxun（赵尔巽）. 1977[1928]. “Monograph on Food No.5-Tea Brewing”(《食货志五·茶法条》 ).In Records of Qing History Vol.124 (《清史稿》卷 124). Beijing: Zhonghua Book Company. 